\title{
ПОРІВНЯЛЬНЕ ВИВЧЕННЯ АМІНОКИСЛОТНОГО СКЛАДУ СУХИХ ПОРОШКІВ БІОМАСИ FLAMMULINA VELUTIPES, ЯКІ ОТРИМАНІ МЕТОДАМИ ПОВЕРХНЕВОГО ТА ГЛИБИННОГО КУЛЬТИВУВАННЯ
}

\author{
(СТ. А. Буткевич, В. П. Попович \\ Національний медичний університет імені О.О. Богомольця \\ ТОВ «ВТФ «ЕКМІ», м. Українка
}

\begin{abstract}
Резюме: у сухих порошках біомаси лікарського гриба Flammulina velutipes, які отримані поверхневим та глибинним культивуванням, визначено якісний та кількісний вміст 17 амінокислот, у тому числі 7 незамінних.

Ключові слова: біомаса, Flammulina velutipes, поверхневе культивування, глибинне культивування, амінокислоти, рідинна хроматографія.
\end{abstract}

Вступ. Лікарський гриб Flammulina (F.) velutipes здавна використовують у народній та офіцинальній медицині країн Сходу як імуномодулюючий, протипухлинний, антиоксидантний, гіпотензивний, антибактеріальний, протигрибковий, противірусний засіб $[5,6]$ та є перспективним джерелом біологічно активних сполук для забезпечення фізіологічних функцій організму необхідними речовинами та енергією.

За попередніми дослідженнями визначено полісахаридний вміст у біомасі $F$. velutipes [7], яку запропоновано отримувати сучасними методами мікробіологічного синтезу - поверхневим та глибинним культивуванням. Продовжуючи роботу з вивчення біологічно активних речовин лікарського гриба, ми провели визначення амінокислотного складу сухого порошку біомаси.

Амінокислоти широко застосовують у медицині при лікуванні нервово-психічних розладів, ряду захворювань шлунково-кишкового тракту, печінки, для профілактики атеросклерозу, підвищення імунітету, пригнічення розвитку злоякісних пухлин тощо [1 - 4].

Отже, метою роботи було порівняльне вивчення якісного складу та кількісного вмісту амінокислот сухих порошків міцеліальної біомаси гриба F. velutipes, які отримано методами поверхневого та глибинного культивування.

Методи дослідження. Об'єкти дослідження - сухі порошки біомаси лікарського гриба $F$. velutipes, які отримано двома методами мікробіологічного синтезу - поверхневим та глибинним культивуванням макроміцетів.

Вирощування біомаси здійснювали у мікробіологічних матрацах з об'ємом 500 мл суспензії $\mathrm{CO}_{2}$-шроту амаранту (60 г/л) у воді очищеній (живильне середовище) при температурі $(26 \pm 1)^{\circ} \mathrm{C}, \mathrm{pH}$ середовища - 6,0. Відокремлену від культуральної рідини біомасу висушували у вакуумній ліофільній сушарці Cryodos-500 (Terrasa, Іспанія).

Амінокислотний склад сухого порошку вивчали 3 використанням автоматичного амінокислотного аналізатора T-339 («Mikrotechna», Прага, Чехія) методом іонообмінної рідинної хроматографії на базі лабораторії Інституту біохімії імені О. В. Палладіна НАН України під керівництвом головного спеціаліста М.П.Мясникової.

Результати експериментів оброблено методами математичної статистики з використанням програм статистичного аналізу Microsoft Office Excel.

Результати й обговорення. У результаті проведених досліджень у сухому порошку біомаси F. velutipes було ідентифіковано 17 амінокислот, серед яких 7 незамінних (валін, ізолейцин, лейцин, лізин, метіонін, треонін, фенілаланін), 2 умовно незамінних (аргінін та гістидин) та 8 замінних амінокислот (аланін, аспарагінова кислота, гліцин, глутамінова кислота, пролін, серин, тирозин, цистин). Сухі порошки біомаси, які отримані різними методами мікробіологічного синтезу (поверхневим та глибинним), не відрізняються за якісним вмістом амінокислот (табл. 1).

Проте, як видно з даних таблиці 1, сухий порошок біомаси лікарського гриба, який отриманий методом поверхневого культивування, містить у 1,41 раза більше амінокислот (незамінних у 1,27 раза більше, замінних - у 1,46 раза).

У сумарному співвідношенні серед замінних амінокислот сухого порошку біомаси, яка отри-

ISSN 2312-0967. Pharmaceutical review. 2015. № 1 
Фітохімічні дослідження

Phytochemical researches

Таблиця 1. Амінокислотний склад сухих порошків біомаси F. velutipes, які отримані у поверхневій та глибинній культурах

\begin{tabular}{|c|c|c|c|c|}
\hline \multirow{2}{*}{ Амінокислоти } & \multicolumn{2}{|c|}{$\begin{array}{c}\text { Сухий порошок біомаси, який } \\
\text { отриманний у глибинній культурі }\end{array}$} & \multicolumn{2}{|c|}{$\begin{array}{c}\text { Сухий порошок біомаси, який } \\
\text { отриманний у поверхневій культурі }\end{array}$} \\
\hline & $\begin{array}{l}\text { кількість } \\
\text { мг/100 мг }\end{array}$ & $\%$ & $\begin{array}{l}\text { кількість } \\
\text { мг/100 мг }\end{array}$ & $\%$ \\
\hline \multicolumn{5}{|c|}{ Незамінні амінокислоти } \\
\hline Валін & 0,825 & 4,45 & 0,969 & 3,72 \\
\hline Ізолейцин & 0,636 & 3,43 & 0,756 & 2,90 \\
\hline Лейцин & 1,408 & 7,59 & 1,618 & 6,21 \\
\hline Лізин & 0,673 & 3,63 & 1,278 & 4,90 \\
\hline Метіонін & 0,387 & 2,09 & 0,481 & 1,85 \\
\hline Треонін & 0,841 & 4,54 & 1,058 & 4,06 \\
\hline Фенілаланін & 0,833 & 4,49 & 0,959 & 3,68 \\
\hline$\sum_{1}$ & 5,603 & 30,22 & 7,119 & 27,32 \\
\hline \multicolumn{5}{|c|}{ Замінні амінокислоти } \\
\hline Аланін & 1,246 & 6,72 & 1,591 & 6,10 \\
\hline Аргінін* & 0,950 & 5,12 & 2,108 & 8,09 \\
\hline Аспарагінова кислота & 1,561 & 8,41 & 2,039 & 7,82 \\
\hline Гістидин* & 0,400 & 2,15 & 0,601 & 2,31 \\
\hline Гліцин & 1,362 & 7,34 & 1,729 & 6,63 \\
\hline Глутамінова кислота & 3,026 & 16,31 & 4,655 & 17,86 \\
\hline Пролін & 1,113 & 6,00 & 1,725 & 6,62 \\
\hline Серин & 1,248 & 6,73 & 1,781 & 6,83 \\
\hline Тирозин & 0,728 & 3,92 & 0,944 & 3,62 \\
\hline Цистин & 1,313 & 7,08 & 1,773 & 6,80 \\
\hline$\sum_{2}$ & 12,947 & 69,78 & 18,946 & 72,68 \\
\hline$\sum_{3 a 2}$ & 18,550 & 100,00 & 26,065 & 100,00 \\
\hline$\sum_{1} / \sum_{2}$ & 0,43 & & 0,38 & \\
\hline
\end{tabular}

Примітка. * - умовно незамінні амінокислоти (аргінін - для дітей та осіб похилого віку; гістидин - для дітей).

мана у глибинній культурі, переважають моноамінокарбонові (аланін, гліцин, серин, тирозин, цистин) - 5,897 мг/100 мг, дещо меншим є вміст моноамінодикарбонових кислот (аспарагінова, глютамінова) - 4,587 мг/100 мг.

Серед замінних амінокислот сухого порошоку біомаси, яка отримана при поверхневому культивуванні $F$. velutipes, домінують також моноамінокарбонові кислоти - 7,818 мг/100 мг. Кількість моноамінодикарбонових кислот складає 6,694 мг/100 мг, гетероциклічних - 2,326 мг/ 100 мг, дикарбонових - 2,108 мг/100 мг.

Аналізуючи вміст незамінних амінокислот у досліджуваних порошках, варто відмітити різні показники їх кількостей та співвідношень. Так, у біомасі, яка отримана у глибинній культурі, переважають лейцин (1,408 мг/100 мг), треонін (0,841 мг/100 мг), фенілаланін (0,833 мг/ 100 мг) та валін (0,825 мг/100 мг) - моноамінокарбонові кислоти. Лейцину також найбіль- ше міститься (1,618 мг/100 мг) у сухому порошку біомаси $F$. velutipes, який отриманий при поверхневому культивуванні. Вміст треоніну (1,058 мг/100 мг) значно поступається вмісту діамінокарбонової кислоти - лізину (1,278 мг/ 100 мг).

Висновки. 1. За допомогою іонообмінної рідинної хроматографії у сухих порошках біомаси лікарського гриба $F$. velutipes, які отримані поверхневим та глибинним культивуванням, було ідентифіковано 17 амінокислот, серед яких 7 незамінних, 2 умовно незамінних та 8 замінних. Домінуючою з незамінних амінокислот у обох досліджуваних порошках $€$ лейцин, із замінних - глутамінова та аспарагінова кислоти.

2. Поверхневе культивування лікарського гриба F. velutipes дозволяє отримати у 1,41 раза більше вільних амінокислот порівняно із глибинним методом вирощування.

ISSN 2312-0967. Фармацевтичний часопис. 2015. № 1 


\section{Література}

1. Гонтова Т. М. Вивчення амінокислотного складу густих екстрактів з трави та коренів живокосту лікарського / Т. М. Гонтова // Український медичний альманах. - 2013. - Т. 16, № 2. - С. 22-23.

2. Кобзар А. Я. Фармакогнозія в медицині / А. Я. Кобзар. - К. : Медицина, 2007. - 544 с.

3. Сухинина Т. В. Аминокислотный состав растений рода EUPHRASIA L. / T. В. Сухинина // Современные вопросы теории и практики лекарствоведения: сб. материалов науч.-практ. конф. с междунар. участием, посвящ. 25-летию фармац. фак. ЯГМА. - Ярославль. - 2007. - С. 314-318.

4. Чекман І. С. Клінічна фітотерапія / І. С. Чекман. К. : Вид-во А.С.К., 2003. - 552 с.

5. Flammulina Velutipes (Curt.: Fr.) Singer: An Edible
Mushroom in Northern Forest of Iran and its Antagonistic Activity Against Selected Plant Pathogenic Fungi / A. Borhani, S. M. Badalyan, N. Garibyan [et al.] // International Journal of Biology. - 2011. - Vol. 3, № 2. - P. 162-167.

6. Hassan F. R. H. Mycelial Biomass Production of Enoke Mushroom (Flammulina velutipes) by Submerged Culture / F. R. H. Hassan, M. Ghada, A. T. M. El-Kady // Australian Journal of Basic and Applied Sciences. - 2012. - №6 (7). - P. 603-610.

7. Butkevych T. A. Mycelial and polysaccharides production of Flammulina velutipes / T. A. Butkevych, V. P. Popovych, N. O. Koziko // Сучасні досягнення фармацевтичної технології та біотехнології : матер. IV наук. практ. конф. з міжнар. уч., 16-17 жовтня, 2014 р. - Х. : Вид-во НФаУ, 2014. - C. 5.

\section{СРАВНИТЕЛЬНОЕ ИЗУЧЕНИЕ АМИНОКИСЛОТНОГО СОСТАВА СУХИХ ПОРОШКОВ БИОМАССЫ FLAMMULINA VELUTIPES, ПОЛУЧЕННЫХ МЕТОДАМИ ПОВЕРХНОСТНОГО И ГЛУБИННОГО КУЛЬТИВИРОВАНИЯ}

\section{Т. А. Буткевич, В. П. Попович}

Национальный медицинский университет имени А. А. Богомольца ООО «ПТФ «ЭКМИ», г. Украинка

Резюме: в сухих порошках биомассы лекарственного гриба Flammulina velutipes, полученных поверхностным и глубинным культивированием, определено качественное и количественное содержание 17 аминокислот, в том числе 7 незаменимых.

Ключевые слова: биомасса, Flammulina velutipes, поверхностное культивирование, глубинное культивирование, аминокислоты, жидкостная хроматография.

\section{COMPARATIVE STUDY OF THE AMINO ACID COMPOSITION OF FLAMMULINA VELUTIPES BIOMASS DRY POWDERS THAT WERE OBTAINED IN STATIC CONDITIONS AND BY SUBMERGED CULTURE}

\section{T. A. Butkevych, V. P. Popovych}

National Medical University by O. O. Bohomolets «PTF «Acme»Co. Ltd, Ukrayinka

Summary: qualitative composition and quantitative content of 17 amino acids, including 7 essential were defined in Flammulina velutipes medicinal mushroom's biomass dry powders. Biomass powders were received in static conditions and by submerged culture.

Key words: biomass, Flammulina velutipes, cultivation in static conditions, submerged culture, aminoacids, liquid chromatography. 